\title{
喘息小児におけるゴキブリ特異的 $\operatorname{IgE}$ 抗体の測定と
}

\section{家庭内ゴキブリアレルゲン量の検討}

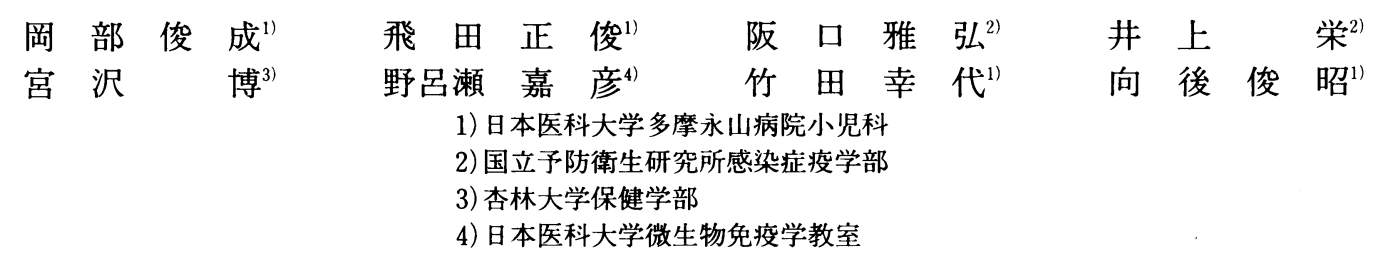

key words : asthmatic children, cockroach specific $\operatorname{IgE}$, cockroach allergen

\section{要旨}

気管支喘息小児 20 例について，ゴキブリ特異的 $\operatorname{IgE}$ 抗体の測定を行い，その陽性率は，クロゴキブリが $25 \%$

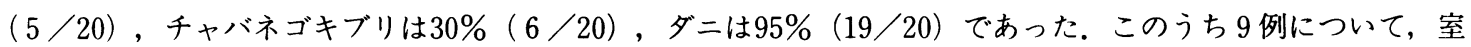
内アレルゲンの検索を行い, クロゴキブリ主要アレルゲン（Perf1）を 4 例で検出したが, チャバネゴキブリ主 要アレルゲン（Bla g 2）は検出できなかった．ゴキブリ特異 IgE 抗体とアレルゲンともに陽性であった症例は, アレルゲンおよび抗体の両者を検索し得た 9 例中の 1 例のみであった。ゴキブリ特異的 $\operatorname{IgE}$ 抗体陽性群と㓌性 群の室内夕゙ニ（Der 1） アレルゲン量の比較では, 子供部屋, 台所, 居間で両群間に有意な差はなかった。

\section{はじめに}

気管支喘息の吸入抗原として重要なものに，昆虫抗

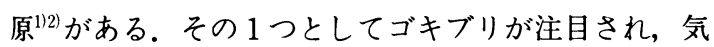
管支喘息の原因の 1 つとして報告されている3 ${ }^{345)}$ 。本 邦においても，小児でのゴキブリ特異 $\operatorname{IgE}$ 抗体の測 定677)，そのアレルゲンの検索索についての報告が散見 され，吸入アレルゲンとしての重要性が指摘されてい る.

今回, 当科外来通院中の気管支喘息患児を对象に, ゴキブリ特異 $\mathrm{IgE}$ 抗体の測定，および，その一部の 患児の家庭内ゴキブリ アレルゲン量の検索を行い， その頻度を見るとともに，家庭内環境についてのアン ケート調查を行い，ゴキブリ特異 $\operatorname{IgE}$ 抗体，および アレルゲンの検出との関連を検討した。また，ゴキブ リ特異 IgE 抗体陽性例と陰性例での臨床的所見の相 違についても比較検討した。

\section{対象および方法}

当科外来通院中の気管支喘息患児20名（表 1）につ いて，1993年11月から1994年 3 月の期間に検討した.
対象とした児は 2 歳より17歳まで，平均年齢10.5歳で， アトピー性皮膚炎合併20例中 9 例, IgE RIST 值は, $35 \sim 10864 \mathrm{IU} / \mathrm{ml}$, 平均 $1691.7 \pm 3403.3 \mathrm{IU} / \mathrm{ml}, \mathrm{IgE}$ RAST 陽性項目数は，20項目検討中，平均 $5.3 \pm 2.3$ 項目であった。この 20 例についてゴキブリ特異 IgE 抗体の測定をファーマシア製 CAP-RASTにて行っ た.さらに, この 20 例中 9 例について, 居間, 台所お よび子供部屋をナショナル製ハンドクリーナーHCV12 にて約 $6 \mathrm{~m}^{2}$ を約 5 分間満遍なく吸引し，それぞれ の場合での家塵を採取した7)。この家塺につき，ク口 ゴキブリ主要アレルゲン $(\operatorname{Per} \mathrm{f} 1) ，$ チャバネゴキブ リ主要アレルゲン（Bla g 2），およびダニ主要アレ ルゲン（Der 1）を検索した. Perf1, Der 1アレルゲ ンの測定は, Schou ${ }^{8)}$, Sakaguchi' ${ }^{9)}$ ら方法に従い, Bla g 2アレルゲンについては, Pollartら ${ }^{10)}$ が報告した 方法に従い, ELISA 法にて測定した。

また, アレルゲンの検索をした 9 例を含め全11例に ついてはアンケート用紙を渡し, 家庭内環境について も検討した。ささらに抗原特異 $\operatorname{IgE}$ 陽性例と陰性例に ついて臨床所見の比較検討を行った。

それぞれの検索については，両親の承諾を得，その 協力のもとに行った. 
表 1 . 対象症例

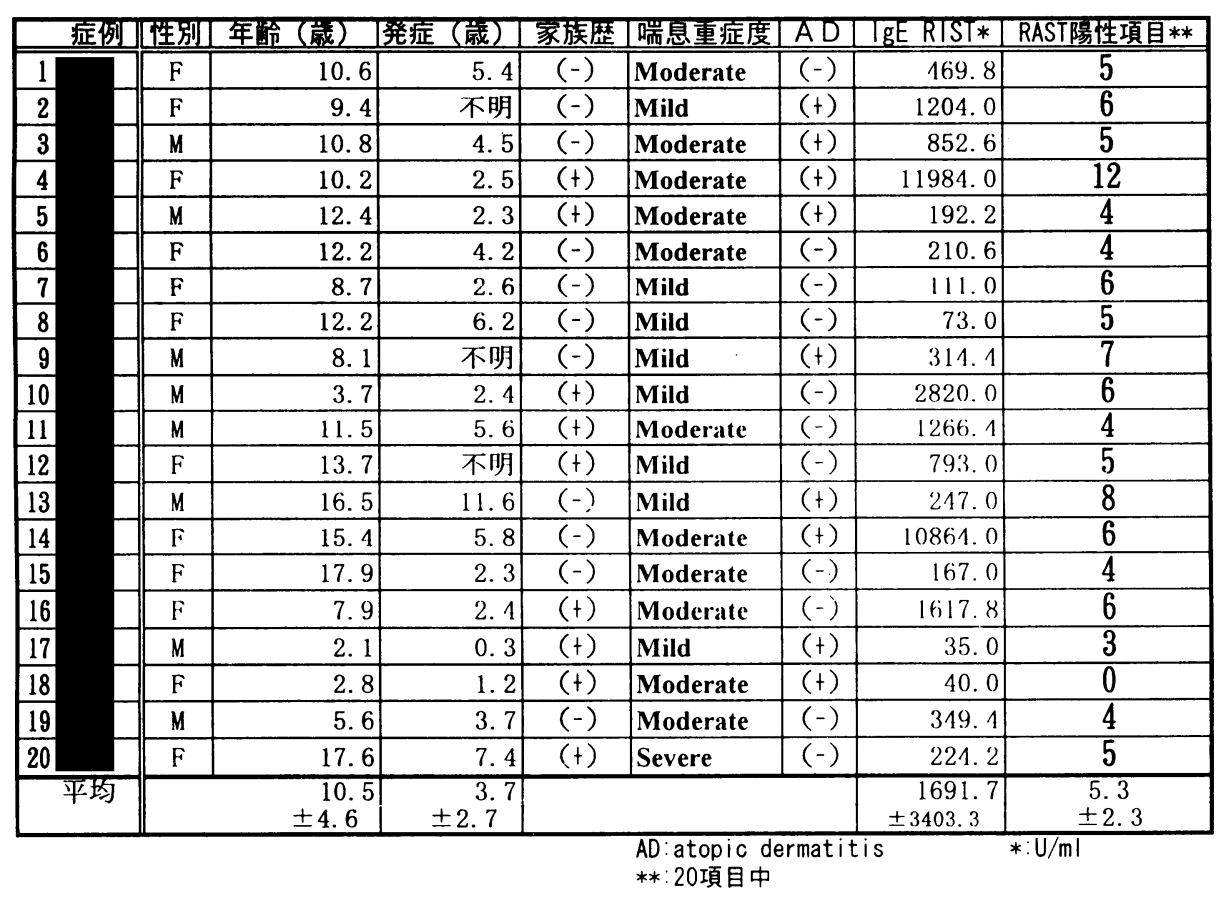

結 果

1）血清ダニ，ゴキブリ特異 $\operatorname{IgE}$ 抗体陽性率：

表 2 に, 各々の患児の血中特異 $\mathrm{IgE}$ 值を示した。 夕゙二特異 IgE 抗体は，20例中19例，95\%に陽性であ ク，クロゴキブリ特異 $\operatorname{IgE}$ は，20例中 5 例， $25 \%$, チャバネゴキブリ特異 IgE は 20 例中 6 例， $30 \%$ に陽 性であった。

2 ）家庭内ゴキブリアレルゲン検出状況：

表 3 に，血清ゴキブリ特異 $\operatorname{IgE}$ 抗体陽性の児の家 庭内ダニ, ゴキブリアレルゲンの検出状況を示した。 クロゴキブリ主要アレルゲンである Perf 1 は 3 例中 1 例のみに検出され, そのアレルゲン量は, 台所が最 も多く, $1.56 \mu \mathrm{g} / \mathrm{g}$ fine dust であり, 居間, 子供部 屋は, 各々, $0.034,0.022 \mu \mathrm{g} / \mathrm{g}$ fine dust であった. 同時に検索した, ダニアレルゲン Der 1 は, 居間に最 も多く検出され， $13.6 \mu \mathrm{g} / \mathrm{g}$ fine dust ついで子供部 屋, 台所の順であった。

表 4 には，ゴキブリ特異 $\mathrm{IgE}$ 抗体陰性例 6 例の室 内塵中の，ダニ主要アレルゲン (Der 1)，ゴキブリ 主要アレルゲン（Perf 1, Blag 2) についての検索結 果を示した。 Der 1は検索した全例, 全室に検出され, 子供部屋, 居間, 台所の順に各々, 平均 $7.50,7.39$,
表 2.ダニ，クロゴキブリおよびチャバネゴキブリの 特異 IgE CAP Score

\begin{tabular}{|c|c|c|c|}
\hline I症例 & 年= & 的丰文 & 千ヤハ社キプ \\
\hline 1 & 5 & 0 & 0 \\
\hline 2 & 6 & 3 & 2 \\
\hline 3 & 6 & 0 & 0 \\
\hline 4 & 5 & 1 & 1 \\
\hline 5 & 5 & 0 & 0 \\
\hline 6 & 5 & 0 & 0 \\
\hline 7 & 4 & 0 & 0 \\
\hline 8 & 4 & 0 & 0 \\
\hline 9 & 4 & 0 & 0 \\
\hline 10 & 5 & 0 & 1 \\
\hline 11 & 5 & 0 & 0 \\
\hline 12 & 6 & 0 & 0 \\
\hline 13 & 4 & 2 & 2 \\
\hline 14 & 6 & 1 & 1 \\
\hline 15 & 4 & 0 & 0 \\
\hline 16 & 6 & 1 & 1 \\
\hline 17 & 5 & 0 & 0 \\
\hline 18 & 0 & 0 & 0 \\
\hline 19 & 5 & 0 & 0 \\
\hline 20 & 5 & 0 & 0 \\
\hline |陽性率 & $\begin{array}{l}19 / 20 \\
(95 \%)\end{array}$ & $\begin{array}{c}5 / 20 \\
(25 \%)\end{array}$ & $\begin{array}{c}6 / 20 \\
(30 \%)\end{array}$ \\
\hline
\end{tabular}

$1.87 \mu \mathrm{g} / \mathrm{g}$ fine dust であった. Perf 1 についてみる と, 6 例中 3 例に検出され, 1 例は, 台所, 居間, 子 供部屋, 3 力所より，1 例は, 居間, 子供部屋 2 力所 
表 3.ゴキブリ特異 $\operatorname{IgE}$ 抗体陽性例の室内塵中の夕 二,ゴキブリアレルゲン量

\begin{tabular}{|c|c|c|c|c|}
\hline 部位 & 症例 & Der 1 & Perf 1 & Blag 2 \\
\hline \multirow[t]{4}{*}{ 台所 } & & n. d. & n. d. & n. d. \\
\hline & & 1.79 & 1.56 & $<0.08$ \\
\hline & & 5.06 & $<0.02$ & $<0.08$ \\
\hline & 平均 & $3.42 \pm 2.3$ & & \\
\hline \multirow[t]{4}{*}{$y t^{*}: \eta^{*}$} & & 1.65 & $<0.02$ & $<0.08$ \\
\hline & & 8.78 & 0.034 & $<0.08$ \\
\hline & & 13.6 & $<0.02$ & $<0.08$ \\
\hline & 平均 & $8.01 \pm 6.0$ & & \\
\hline \multirow[t]{4}{*}{ 腺室/子供室 } & & 4.12 & $<0.02$ & $<0.08$ \\
\hline & & 10.6 & 0.022 & $<0.08$ \\
\hline & & 10.8 & $<0.02$ & $<0.08$ \\
\hline & 平均 & $7.36 \pm 4.6$ & & \\
\hline
\end{tabular}

表 4.ゴキブリ特異 $\operatorname{IgE}$ 抗体除性例の室内塵中の夕゙ 二,ゴキブリアレルゲン量

\begin{tabular}{|c|c|c|c|c|}
\hline 郘位 & 泟例 & Der 1 & Per 11 & Bla g 2 \\
\hline \multirow[t]{7}{*}{ 台所 } & & 0.186 & $<0.02$ & $<0.08$ \\
\hline & & 0.34 & $<0.02$ & $<0.08$ \\
\hline & & 2.06 & 0.024 & $<0.08$ \\
\hline & & 3.09 & $<0.02$ & $<0.08$ \\
\hline & & 0.134 & $<0.02$ & $<0.08$ \\
\hline & & 5.38 & 0.02 & $<0.08$ \\
\hline & 平均 & $1.87 \pm 2.11$ & $0.022 \pm 0.002(n=2)$ & \\
\hline \multirow[t]{7}{*}{ 㧹ング } & & 5.97 & $<0.02$ & $<0.08$ \\
\hline & & 10.4 & $<0.02$ & $<0.08$ \\
\hline & & 3.09 & 0.04 & $<0.08$ \\
\hline & & 9.18 & $<0.02$ & $<0.08$ \\
\hline & & 0.612 & 0.032 & $<0.08$ \\
\hline & & 15.1 & $<0.02$ & $<0.08$ \\
\hline & 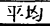 & $7.39 \pm 5.26$ & $0.036 \pm 0.006(n=2)$ & \\
\hline \multirow[t]{7}{*}{ 了供宗 } & & 0.741 & $<0.02$ & $<0.08$ \\
\hline & & 1.81 & $<0.02$ & $<0.08$ \\
\hline & & 5.93 & 0.02 & $<0.08$ \\
\hline & & 1.15 & $<0.02$ & $<0.08$ \\
\hline & & 5.72 & 0.02 & $<0.08$ \\
\hline & & 26.6 & $<0.02$ & $<0.08$ \\
\hline & \%均 & $7.50 \pm 9.62$ & $0.02(n=2)$ & \\
\hline
\end{tabular}

から，1例は台所のみから検出され， 2 例ずつの平均 は居間, 台所, 子供部屋 $0.036,0.022,0.02 \mu \mathrm{g} / \mathrm{g}$ fine dustであった。なおチャバネゴキブリの主要アレ ルゲン Bla g 2は 9 例中 1 例も検出されなかった。

3 ）ゴキブリ特異 IgE 抗体とアレルゲンの有無との 関係：

表 5 は, ゴキブリ特異 $\operatorname{IgE}$ 抗体測定と, アレルゲ ンの検索結果の関連を示したものである．抗体の測定 とアレルゲンの検索をともに行い得た 9 例についてみ ると，ゴキブリ特異 $\operatorname{IgE}$ 抗体が陽性で室内アレルゲ ンの検出されたものは， 3 例中 1 例であり，ゴキブリ 特異 $\operatorname{IgE}$ 抗体陰性で, 室内アレルゲン陽性のものは 6 例中 3 例あった。また，ゴキブリ特異 IgE 抗体は 陽性でも，室内アレルゲン陰性のものも 2 例あった。 ゴキブリ特異 $\mathrm{IgE}$ 抗体と室内アレルゲンがともに陽 性だったものは 1 例のみであった。

4）ゴキブリ特異 $\mathrm{IgE}$ 抗体陽性例と陰性例の夕゙ニア レルゲン量の比較：

ゴキブリ特異 $\mathrm{IgE}$ 抗体陽性例と陰性例での室内環 境を評価するために, 室内ダニアレルゲン量の比較検 討を行った。図 1 は，血清ゴキブリ特異 $\operatorname{IgE}$ 抗体陽 表 5. 室内 Perf 1 アレルゲンおよびクロゴキブリ特 異 IgE 抗体を同時に測定し得た 9 症例のアレ ルゲン，抗体の検出パターン

\begin{tabular}{|c||c|c|}
\hline & 血清挖体 $(+)$ & 血清抗体 $(-)$ \\
\hline \hline 室内アレルゲン $(+)$ & 1 & 3 \\
\hline 室内アレルゲン $(-)$ & 2 & 3 \\
\hline
\end{tabular}

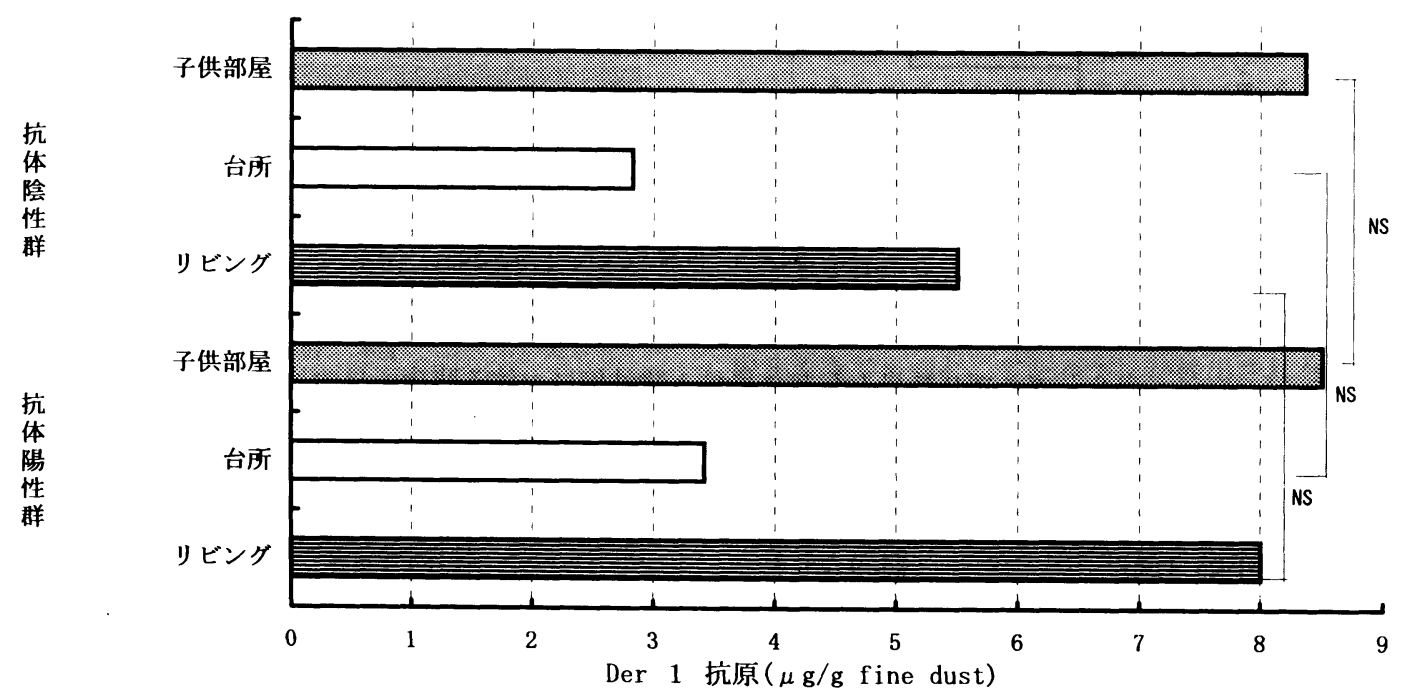

図 1.クロゴキブリ特異 $\operatorname{IgE}$ 抗体陽性群 $(\mathrm{n}=3)$ と除性群 $(\mathrm{n}=6)$ の平均 Der 1 アレルゲン量の比較 
性群 3 例と陰性群 6 例でのアレルゲン量を各部屋で比 較したものである。ゴキブリ特異 $\operatorname{IgE}$ 抗体陽性群で は, 子供部屋, 台所, 居間, 各々平均で $8.51,3.42$, $8.01 \mu \mathrm{g} / \mathrm{g}$ fine dust, 陰性群では各々平均 $8.37,2.83$, $5.51 \mu \mathrm{g} / \mathrm{g}$ fine dust と, 両群に有意な差は見られな かった.

5 ）ゴキブリアレルゲン検出群と非検出群のダニアレ ルゲン量の比較：

上記と同様の目的で, ゴキブリ主要アレルゲン Per $\mathrm{f} 1$ 陽性 3 例と陰性 6 例について，それぞれの家庭で のダニアレルゲンのアレルゲン量について比較した

（図 2 ）. 子供部屋, 台所, 居間の順に, 陰性群で, 各々平均 $8.37,7.38,5.51 \mu \mathrm{g} / \mathrm{g}$ fine dust, 陽性群で は各々 $8.51,3.42,8.01 \mu \mathrm{g} / \mathrm{g}$ fine dust と両群で有 意な差は認められなかった。

Der 1のアレルゲン量は, 両群とも子供部屋が最も 多く，次に居間，最も少ないのが台所であった。

6 ）ゴキブリ特異 $\operatorname{IgE}$ 抗体陽性例と陰性例での臨床 所見の比較：
ゴキブリアレルゲンと特異 $\operatorname{IgE}$ 抗体両者の測定を 行った 9 例と，ゴキブリ特異 $\operatorname{IgE}$ 抗体のみ測定した ものも11例の計20例について，ゴキブリ特異 $\operatorname{IgE}$ 抗 体陽性例と，陰性例で臨床的な違いについて検討した．

表 6 のごとく 2 群で, 重症度, 平均年齢, 発症年齢, 増悪季節, IgE RIST值, IgE RAST 陽性項目数を比 較したが，両群で明らかな差異はみられなかった。

7 ）ゴキブリ特異 $\mathrm{IgE}$ 抗体陽性例と陰性例でのアン ケートによる環境因子の検討：

家庭内家塵中のゴキブリアレルゲンの測定を行った 9 例を含め, ゴキブリ特異 $\operatorname{IgE}$ 抗体陽性群と陰性群 で，アンケートによる家庭内環境を比較検討した結果 を示した（図 3 ）。

家庭環境として, 住宅, 暖房, 布団の種類, 絨毯, ペット飼育, ソファ，ぬいぐるみおよび家庭内での 契煙者の有無，さらにアレルギーの家族歴につき検討 した．住宅はコンクリート住宅と木造住宅が両群ほぼ 半数ずつであり，暖房も複数回答にしたため，石油を 使うものと, 電気によるものほぼ半数ずつで, 䋐廹も

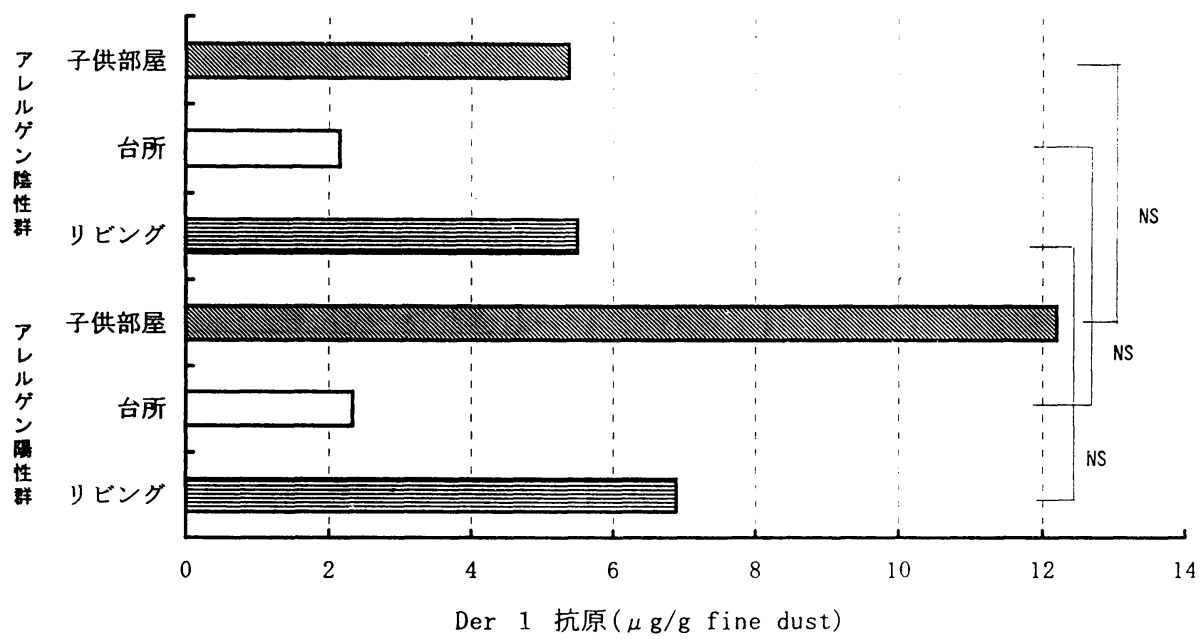

図 2. 家塵中 Perf1アレルゲン陽性群 $(\mathrm{n}=4)$ と陰性群 $(\mathrm{n}=5)$ のDer 1 アレルゲン量の比較

表 6 ．ゴキブリ特異 $\mathrm{IgE}$ 抗体陽性と陰性例における臨床所見の比較

\begin{tabular}{|c|c|c|}
\hline & 臣キブリ抗体陽性例 & ב“キブリ抗体陰性例 \\
\hline 症例数 $(n)$ & 6 & 14 \\
\hline 性別 (男 : 女) & $3: 3$ & 5 \\
\hline 平均年龄 (歲) & $8.9 \pm 4.4$ & $11.1 \pm 4.7$ \\
\hline 平均発症年齢 (歳) & $4.5 \pm 4.0$ & $4.0 \pm 2.2$ \\
\hline 壃悪季節 & 春 $(5)$, 夏 $(1)$, 秋 $(6)$, 冬 (1) & 春 (13), 夏 (7), 秋 (14), 冬 (3) \\
\hline 宁卜ピー性皮膚炎合併例 & 3 & 6 \\
\hline $\operatorname{IgE} \operatorname{RIST}(\mathrm{U} / \mathrm{ml})$ & $3037.7 \pm 4482.7$ & $1025.9 \pm 2844.0$ \\
\hline $\operatorname{IgE} R \Lambda S T$ (陽性項目数) & $7.0 \pm 2.8$ & $4.5 \pm 1.7$ \\
\hline
\end{tabular}


両群とも $80 \%$ に使用しており, 両群に差はなく, 布団 の種類も一定の傾向は見られなかった。ペットは，両 群ともに飼育しているものはなかった。しかし，契煙

住安

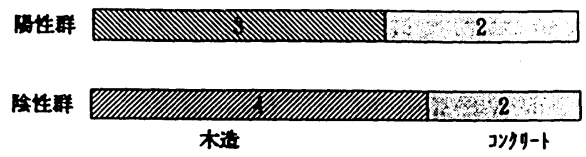

昵の程数

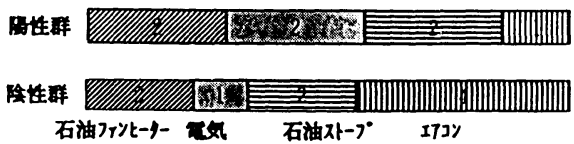

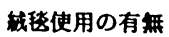

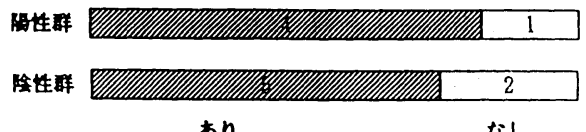

動物姛育の有無

\section{的群}

㛺甠

家廷内でタパコ哭社の有無

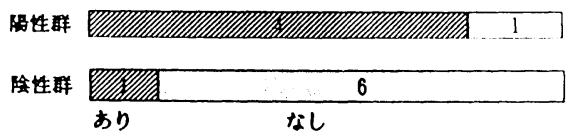

ソファの有無

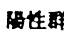

4

格甠

おり

ぬいぐろみの有無

\section{提群}

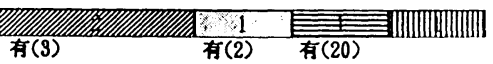

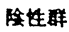

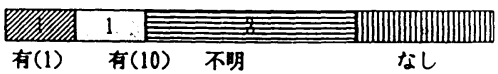

家故厓

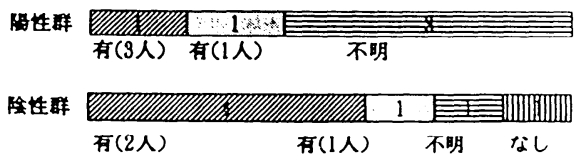

図 3.クロゴキブリ特異 $\operatorname{IgE}$ 抗体陽性群, 陰性群の アンケートによる環境因子の比較

（陽性 5 名, 陰性 7 名)
については，陽性群の 8 割の家庭に喫煙者がいるのに 对し，陰性群では 7 例中 1 例のみに喫煙者がいただけ であった。ソファーの有無に関しては逆に，陽性群の 8 割（5 例中 1 例）で使用していないのに比し, 陰性 群では 7 家族中すべての家庭で使用しているとの回答 であった。この 2 点については両群で有意差を認めた。 その他, ぬいぐるみの有無, 家族歴では差は認められ なかった。

\section{考案}

今回，気管支喘息児20例について，クロゴキブリ， チャバネゴキブリおよびダ二特異的血清 $\mathrm{IgE}$ 抗体の 測定を CAP 法で行い，各々 $25 \% ， 30 \% ， 95 \% に$ 陽性 であった。より多くの症例でゴキブリ特異 $\operatorname{IgE}$ 抗体 を測定した阪口ら゙はクロゴキブリ抗体は $16 \%$ に，千ャ バネゴキブリ抗体は $9.9 \%$ に陽性だったと報告してい る. $\operatorname{Lan} ら^{4)}$ は成人気管支喘息を对象として，ゴキブ リ抗原を用いた Skin testでの陽性率は57.5\%，FAST では $44.9 \% に$ に抗体が陽性だったと報告している。ま た，アレルギーを持った小児においては，ゴキブリ抗 原を用いた Skin test で38\%の陽性率であったとの報 告もある

今回のゴキブリ特異 $\operatorname{IgE}$ 抗体陽性率は, 阪口らの 報告より若干高いが，その他のものと比較するとむし ろ低い傾向にあった。これには，測定した時期が比較 的ゴキブリアレルゲンの少ない時期であったこと，ま た, 対象とした症例が, 当院の近辺の団地を中心とす る地域に限られており，こうした地域環境の差も影響 しているものと思われた。また，チャバネゴキブリと クロゴキブリがほぼ同程度の陽性率であったのは, CAP-RASTにおいて，両ゴキブリ間の交差反応があ る11ことが一因であると考えられる。

ゴキブリアレルゲン抗原の検索によりアレルゲンの 検出ができたのは，9例中 4 例で, 全検索場所 40 力所 中 9 力所であった。アレルゲンが検出された 4 症例の 内訳は，ゴキブリ特異 $\operatorname{IgE}$ 抗体陽性群 3 例中に 1 例, 㓌性群 6 例中 3 例で，アレルゲンはいずれもクロゴキ ブリ主要アレルゲン（Perf 1) であった。

また，ゴキブリ特異 $\operatorname{IgE}$ 抗体と，または家庭内ゴ キブリアレルゲンの検出と環境の関連をみる目的で, ゴキブリ特異 $\operatorname{IgE}$ 抗体またはゴキブリアレルゲンの 陽性群と陰性群で, 環境の指標の一つとしてダ二主要 アレルゲンである Der 1 量を比較してみたが，抗体ま 
たはアレルゲンともに，陽性群と陰性群で有意な差は 認められなかった。

さらに，ゴキブリ特異 $\mathrm{IgE}$ 抗体陽性群と陰性群で, アンケートによる家庭内環境を比較検討したところ， ゴキブリ抗体陽性群にタバコの喫煙者がいるものが有 意に多かった。このことは, Fagbule ら ${ }^{12}$ は喘息患児 と非喘息児の環境因子を比較し，喘息児の家庭では喫 煙者が多く，ゴキブリアレルゲンの検出頻度も高いと 報告しており，今回の結果をあわせると，家庭内喫煙 とゴキブリアレルゲンによる感作に何らかの関連があ ることが示唆されるものと思われた。

ソファーに関しては，ゴキブリ抗体陰性群に比し陽 性群では使用しているものは少なく，有意差を認めた． アンケートによる他の家庭内環境については両群に差 はなかった。

ゴキブリアレルゲンと気管支喘息の関連について， 今回は，ゴキブリ抗体陽性者と陰性者の臨床所見の差 異があるか否かの面で検討してみたが, 検討項目にお ける差はなく，かかる面からゴキブリアレルゲンと気 管支喘息の関連を明らかにすることはできなかった。

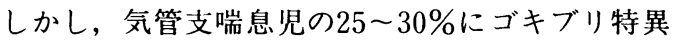
IgE 抗体陽性者がおり，また，喘息患者でゴキブリ抗 原の吸入により 1 秒率の低下をきたすこと ${ }^{45)}$ ，皮内反 応で陽性者のいること放14)の報告もあり，当地域にお いても，ゴキブリ抗原は気管支喘息の吸入抗原の一つ として留意すべきものと考えられた。

本研究の要旨は, 第 43 回日本アレルギー学会総会 (東京)において発表した。

\section{文献}

1) 田中生男：昆虫アレルゲン, 遺伝，48，28-33, 1994.

2 ）木野稔也：吸入性昆虫アレルゲンによる気管支喘 息, 病態生理. 10, 828-831, 1991.

3 ) Bernton.H, McMahon.T, Brown.H : Cockroach asthma. Brit. J. Dis. Chest, 66, 61-66, 1972.

4 ) Lan, J.L., Lee,D.T., Wu, C.H. Chang, C.P., Yeh,C.L. ; Cockroach hypersennsitivity : Preliminary atudy of allergic asthmna in Taiwan. J. Allergy Clin. Immunol. 82, 736-740, 1988.

5 ) Kang. B., Vellody,D., Homburger, H., Yunginger, J.W. : Cockroach cause of allergic asthma Its specificity and immunologic profile. J. Allergy clin. Immun. 63. 80-86, 1979.

6 ）伊藤幸治，須甲松伸，宮本昭正，小林節雄，中澤 次夫, 高橋昭三, 西片光, 根本俊彦, 松原恒雄：昆 虫，ダニアレルゲンディスクを用いた RAST の有 用性の検討，アレルギー，38，413-422， 1989.

7 ) Sakaguchi, M., Inouye,S., Miyazawa, H. Okabe, T., Yasueda, H. , Muto, A., Tanaka,I., Akasaka,T., Wu C.H., Chapman,M., Schou, C.,: Sensitization to cockroach allergens of athma patients in Japan,アレルギー, 43, 1309-1315, 1994.

8 ) Schou, C. , Fernandez-Caldas,E., Lockey, R.F., L $\phi$ wenstein, H. : Enviromental assay for cockroach allergens. J. Allergy Clin. Immunol. 87, 828-834, 1991.

9) Sakaguchi, M., Inouye,S., Irie,T., Miyazawa, H., Watanabe, H, et al.: Airborn cat (Fel d I), $\operatorname{Dog}(\operatorname{Can} f$ I), and mite(Der I and Der II) allergen levels in the home of Japan. J. Allergy Clin. Immunol. 92, 797-802, 1993.

10) Pollart,S.M., Mullines.D.E., Vailes, L.D., Hayden, M.L., Pllats-Mill, T. A. E., et.al. : Identification, quantitation and purification of cockroach allergens using monoclonal anti-bodies. J. Allery Clin. Immunol. 82, 511-521, 1991.

11) Pollart,S.M., Smith, T.F., Morris, E.C., Gelber,L.E., Platts-Mills, T.A.E. and Chapman,M.D. : Environmental exposure to cockroach allergens ; analysis with monoclonal antibody-based enzyme immunoassays. J. Allergy Clin. Immunol. 87, 505-510, 1991.

12) Fagbule,D., Ekanem E.E. : Some environmental risk facters for childhood asthma ; a case-control study. Annals of Tropical Paedia. 14, 15-19, 1994.

13) Mendoza,J., Snyder,R.D. : Cockroach sensitivity in children with bronchial asthma. Annals Allergy, 28, 159-1163, 1970.

14) Kang, B., Sulit, N. : A comparative study of prevalence of skin hypersensitivity to cockroach and house dust antigens. Annals Allergy, 41, 333-336, 1978. 


\title{
SENSITIZATION TO COCKROACH ALLERGENS OF ASTHMATIC CHILDREN AND DETECTION OF COCKROACH ANTIGENS IN HOUSES OF ASTHMATIC CHILDREN
}

\author{
Toshinari Okabe $^{1)}$, Masatoshi Hida ${ }^{1)}$, Masahiro Sakaguchi²), Sakae Inouye ${ }^{2)}$, \\ Hiroshi Miyazawa ${ }^{3)}$, Yoshihiko Norose ${ }^{3)}$, Sachiyo Takeda"), Toshiaki Kougo ${ }^{1)}$ \\ 1) Deparment of Pediatrics, Tama-Nagayama Hospital, Nippon Medical Schoool \\ 2) Department of Epidemiology, National Institute of Health \\ 3) Department of Medical Technology, Kyorin University \\ 4) Department of Microbiology and Immanology Nippon Medical School
}

\begin{abstract}
As part of an attempt to clarify adverse effects of cockroachs and mites upon children suffering from bronchial asthma, measurement has beeen taken of $\mathrm{IgE}$ antibodies specific to two cockroach subspecies (Perplaneta fulginosa and Blattella germanica) and a mite (Dermatophagoides farinae) as for 20 asthmatic children .

Its results indicated that the rates of positivity were $25 \%(5 / 20)$ for Periplanate fulginosa, $30 \%(6 / 20)$ for Blattella germanica, and $95 \%(19 / 20)$ for Dermatophagoides farinae in the sera from the children as they were analyzed under Pharmacia's CAP system.

In nine of the cases, detection attempts were made for allergen in the children's houses, where major allergen of Periplanata fulginosa(Per $\mathrm{f} 1$ ) were actually detected in four cases but major allergen of Blattella germanica(Bla g 2) were not detected.

Of nine cases in which both $\mathrm{IgE}$ antibodies specific to cockroaches and allergens were detected, there was only one case where the antibodies and allergens were positive.

A comparison of the volume of allergens among the positive group of IgE antibodies specific to cockroaches, its negative counterpart, and Dermatophagoides farinae(Der 1) revealed no significant differences among the children's room, kichins and living rooms.
\end{abstract}

(Accepted: September 1, 1995) 